\title{
Theoretical studies of the interaction between enflurane and water
}

\author{
Wiktor Zierkiewicz • Danuta Michalska • \\ Thérèse Zeegers-Huyskens
}

Received: 6 September 2012 / Accepted: 5 November 2012/Published online: 5 December 2012

(C) The Author(s) 2012. This article is published with open access at SpringerLink.com

\begin{abstract}
Increase of the atmospheric concentration of halogenated organic compounds is partially responsible for a change of the global climate. In this work we have investigated the interaction between halogenated ether and water, which is one of the most important constituent of the atmosphere. The structures of the complexes formed by the two most stable conformers of enflurane (a volatile anaesthetic) with one and two water molecules were calculated by means of the counterpoise CP-corrected gradient optimization at the MP2/ 6-311++G(d,p) level. In these complexes the $\mathrm{CH} \ldots \mathrm{O}_{\mathrm{w}}$ hydrogen bonds are formed, with the $\mathrm{H}_{\text {... }} \mathrm{O}_{\mathrm{w}}$ distances varying between 2.23 and $2.32 \AA$. A small contraction of the $\mathrm{CH}$ bonds and the blue shifts of the $v(\mathrm{CH})$ stretching vibrations are predicted. There is also a weak interaction between one of the $\mathrm{F}$ atoms and the $\mathrm{H}$ atom of water, with the $H_{w} \ldots F$ distances between 2.41 and $2.87 \AA$. The $\operatorname{CCSD}(\mathrm{T}) / \mathrm{CBS}$ calculated stabilization energies in these complexes are between -5.89 and $-4.66 \mathrm{kcal}$ $\mathrm{mol}^{-1}$, while the enthalpies of formation are between -4.35 and $-3.22 \mathrm{kcalmol}^{-1}$. The $\mathrm{Cl}$ halogen bonding between enflurane and water has been found in two complexes. The intermolecular $(\mathrm{Cl} \cdots \mathrm{O})$ distance is smaller than the sum of the corresponding van der Waals radii. The CCSD(T)/CBS stabilization energies for these complexes are about $-2 \mathrm{kcalmol}^{-1}$.
\end{abstract}

\footnotetext{
W. Zierkiewicz $(\square) \cdot$ D. Michalska

Faculty of Chemistry, Wrocław University of Technology,

Wybrzeże Wyspiańskiego 27,

50-370 Wrocław, Poland

e-mail: Wiktor.Zierkiewicz@pwr.wroc.pl

T. Zeegers-Huyskens ( $\square$ )

Department of Chemistry, University of Leuven,

200F Celestijnenlaan,

3001 Heverlee, Belgium

e-mail: Therese.Zeegers@chem.kuleuven.be
}

Keywords Anaesthetic $\cdot$ Enflurane $\cdot$ Hydrogen bond $\mathrm{Ab}$ initio MP2 $\cdot \operatorname{CCSD}(\mathrm{T}) \cdot$ Halogen bond

\section{Introduction}

Halogenated ethers bearing several $\mathrm{F}$ or $\mathrm{Cl}$ atoms have been known for many years as narcotic gases. In these derivatives, the presence of one or several halogen atoms tends to make the $\mathrm{CH}$ bonds more acidic, which gives rise to specific interactions with surrounding enzymes and neuroreceptors [1-6]. Enflurane ( $\left.\mathrm{CHClF}-\mathrm{CF}_{2}-\mathrm{O}-\mathrm{CHF}_{2}\right)$, a volatile anaesthetic, is characterized by two $\mathrm{CH}$ bonds which can interact with neighboring molecules. The structures of the stable conformers of this molecule have been reported in earlier works [7-9]. The basicity of enflurane and its interaction with guest molecules have been investigated as well [10-13]. Recently, the atmospheric chemistry of halogenated ethers, such as isoflurane $\left(\mathrm{CF}_{3}-\mathrm{CHCl}-\mathrm{O}-\mathrm{CHF}_{2}\right)$, desflurane $\left(\mathrm{CF}_{3}-\mathrm{CHF}-\mathrm{O}-\mathrm{CHF}_{2}\right)$ and sevoflurane $\left(\left(\mathrm{CF}_{3}\right)_{2}\right.$ $\mathrm{CH}-\mathrm{O}-\mathrm{CH}_{2} \mathrm{~F}$ ) have been studied in the reaction with chlorine atoms and $\mathrm{OH}$ radicals, with respect to the global warming potentials of these compounds [14]. Lane and coworkers [15] studied the reaction of enflurane with chlorine atom and the problems of ozone depletion. These authors estimated the global atmospheric lifetime of enflurane as 3.7 years. It is therefore important to investigate the interaction between halogenated ethers and water, which is one of the major constituents of the atmosphere.

As far as we know, no theoretical or experimental data have been reported for the enflurane-water complexes. Our work is arranged as follows. In the first part, we will discuss the structures, binding energies and enthalpies of formation of the hydrogen bonded enflurane complexes with water. For this purpose, we have chosen the two most stable conformers of enflurane. The stabilization energies of the 
complexes have been determined at the MP2/6-311++G $(\mathrm{d}, \mathrm{p})$ and $\operatorname{CCSD}(\mathrm{T}) /$ complete basis set (CBS) levels of theory. To estimate the role of the cooperativity or anticooperativity effects, the three-body contributions to the total binding energies have been calculated. In the second part, the $\mathrm{Cl}$ halogen bonded complexes between enflurane and water have been investigated at the same levels of theory.

\section{Theoretical methods}

Full geometry optimizations followed by the calculations of vibrational frequencies and infrared intensities were performed for the two most stable conformers of enflurane and their complexes with water using an ab initio second order Møller-Plesset perturbation method combined with the $6-311++\mathrm{G}(\mathrm{d}, \mathrm{p})$ basis set $[16,17]$. The counterpoise CPcorrected gradient optimization, which eliminates the basis set superposition error (BSSE) [18], has been used in all calculations of the minimum energy structures of the complexes investigated.

The proton affinity (PA) as well as the deprotonation energy (DPE) were calculated as the negative enthalpy change and the enthalpy change of the reactions (1) and (2), respectively, assuming standard conditions in the gas phase.

$$
\begin{array}{ll}
\mathrm{AH}_{(\mathrm{g})}+\mathrm{H}_{(\mathrm{g})}{ }^{+} \rightarrow \mathrm{AH}_{2(\mathrm{~g})}{ }^{+} & \mathrm{PA}=-\Delta \mathrm{H}^{298} \\
\mathrm{AH}_{(\mathrm{g})} \rightarrow \mathrm{A}_{(\mathrm{g})}{ }^{-}+\mathrm{H}_{(\mathrm{g})}{ }^{+} & \mathrm{DPE}=\Delta \mathrm{H}^{298}
\end{array}
$$

where $\mathrm{AH}=$ isolated enflurane molecule.

The total stabilization energies of the enflurane-water complexes were determined at the MP2/6-311++G(d,p) and $\operatorname{CCSD}(\mathrm{T}) /$ complete basis set (CBS) levels of theory. The $\operatorname{CCSD}(\mathrm{T}) / \mathrm{CBS}$ stabilization energy was calculated as the sum of the MP2/CBS stabilization energy and the CCSD(T) correction term [19]. The MP2/CBS energy was extrapolated from the MP2 energies evaluated with the aug-cc-pVDZ and aug-ccpVTZ basis sets. The extrapolation method of Helgaker et al. has been used [20]. The $\operatorname{CCSD}(T)$ correction term (the difference between the $\operatorname{CCSD}(\mathrm{T})$ and MP2 interaction energies) was determined with the augcc-pVDZ basis set [21, 22].

Enthalpies of formation of the enflurane-water complexes under standard conditions, in the gas phase, were calculated at the MP2/6-311++G(d,p) and CCSD(T)/CBS levels. The $\operatorname{CCSD}(\mathrm{T}) / \mathrm{CBS}$ enthalpy was determined as the sum of the $\operatorname{CCSD}(\mathrm{T}) / \mathrm{CBS}$ electronic energy and the zero-point vibrational energy and the thermal correction to enthalpy obtained by the MP2/6-311++G(d,p) method.
The evaluation of the three-body contribution $\left(\mathrm{E}_{3 \mathrm{~B}}\right)$ to the total interaction energy $\left(\Delta \mathrm{E}_{\text {int }}\right)$ of the enflurane complex with two water molecules was performed at the MP2/6$311++\mathrm{G}(\mathrm{d}, \mathrm{p})$ and $\operatorname{CCSD}(\mathrm{T}) / \mathrm{CBS}$ levels of theory. The value of $E_{3 B}$ was obtained as the difference between $\Delta E_{\text {int }}$ of the complex and the sum of three pairwise (two-body) interaction energies, $\Delta \mathrm{E}_{2 \mathrm{~B}}$. The negative value of $\mathrm{E}_{3 \mathrm{~B}}$ means a cooperative effect, while the positive one corresponds to an anti-cooperative interaction in the three-body unit [23].

Natural bond orbital (NBO) analysis has been applied to calculate charges on individual atoms, orbital occupancies, hybridizations, and the second-order interaction energy $\left(E^{2}\right)$ between the donor and acceptor orbitals [24]. It should be mentioned that NBO method evaluates the energies of orbitals and the 2nd-order stabilization energies only in this case, when the 1-electron effective Hamiltonian operator is well defined (e.g., Fock or Kohn-Sham operator) [25]. Therefore, in the MP2 calculations, the NBO analysis has been performed at the SCF level. All computations were carried out with the Gaussian 09 set of programs [26].

\section{Results and discussion}

Hydrogen bonded enflurane complexes with water

The two most stable structures of enflurane optimized at the MP2/6-311++G(d,p) level of theory are shown in Fig.1. Conformers I and II differ in energy by only $0.07 \mathrm{kcal}$ $\mathrm{mol}^{-1}$. It should be mentioned that the stability order of the conformers is slightly different from that obtained at the MP2/6-311G(2d) level in our earlier studies [9]. Conformers I and II of the present work correspond to the B and $\mathrm{C}$ conformers of ref [9]. Let us notice that in I, the two $\mathrm{CH}$ bonds are in a trans position, and in II, the two $\mathrm{CH}$ groups adopt the cis position.

The structures of enflurane (I and II) complexes with one water molecule (1-1) are illustrated in Fig. 2. As is seen, in the 1-1 complexes involving both conformers, water interacts with enflurane through $\mathrm{CH} \ldots \mathrm{O}_{\mathrm{w}}$ hydrogen bonds, with the $\mathrm{C}_{1} \mathrm{H}_{5} \ldots \mathrm{O}_{\mathrm{w}}$ or $\mathrm{C}_{4} \mathrm{H}_{12} \ldots \mathrm{O}_{\mathrm{w}}$ distances varying between 2.23 and $2.32 \AA$. Weak interaction between one of the $\mathrm{F}$ atoms and the $\mathrm{H}$ atom of water is also possible, the $\mathrm{H}_{\mathrm{W}} \ldots \mathrm{F}$ distances being much longer (between 2.60 and $2.87 \AA$ ). No stable $\mathrm{O}_{\mathrm{w}} \mathrm{H}_{\mathrm{w}} \ldots \mathrm{O}_{3}$ complex has been found on the potential energy surface. In the Ia complex (Fig. 2), the $\mathrm{H}_{\mathrm{w}} \ldots \mathrm{O}_{3}$ distance is too long $(2.80 \AA)$ to be classified as a true hydrogen bond.

The structures of enflurane complexes with two water molecules (1-2) are shown in Fig. 3. It is important to notice that in these complexes, the intermolecular distances remain approximately the same as in the 1-1 complexes, the $\mathrm{CH}$... $\mathrm{O}_{\mathrm{w}}$ distances varying between 2.23 and $2.34 \AA$, and the 


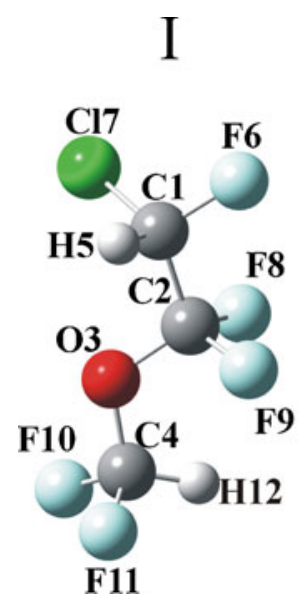

Fig. 1 Structures of two most stable conformers of enflurane optimized at the MP/6-311++G(d,p) level of theory and the numbering of atoms

$\mathrm{O}_{\mathrm{w}} \mathrm{H}_{\mathrm{w}} \ldots \mathrm{F}$ distances being between 2.41 and $2.61 \AA \AA$. In Ia and Ic, the $\mathrm{O}_{13} \mathrm{H}_{14} \ldots \mathrm{F}_{11}$ intermolecular angles are markedly larger $\left(146^{\circ}\right.$ and $152^{\circ}$, respectively) than the $\mathrm{OH} \ldots \mathrm{F}$ intermolecular angles in the remaining complexes $\left(100-110^{\circ}\right)$. Further, the $\mathrm{C}_{4} \mathrm{H}_{12} \ldots \mathrm{O}_{\mathrm{w}}$ hydrogen bonds tend to be more linear than the $\mathrm{C}_{1} \mathrm{H}_{5} \ldots \mathrm{O}_{\mathrm{w}}$. It is worth mentioning that in the enflurane dimer, the $\mathrm{O}_{3}$ atoms do not participate in the interaction. The two enflurane molecules having
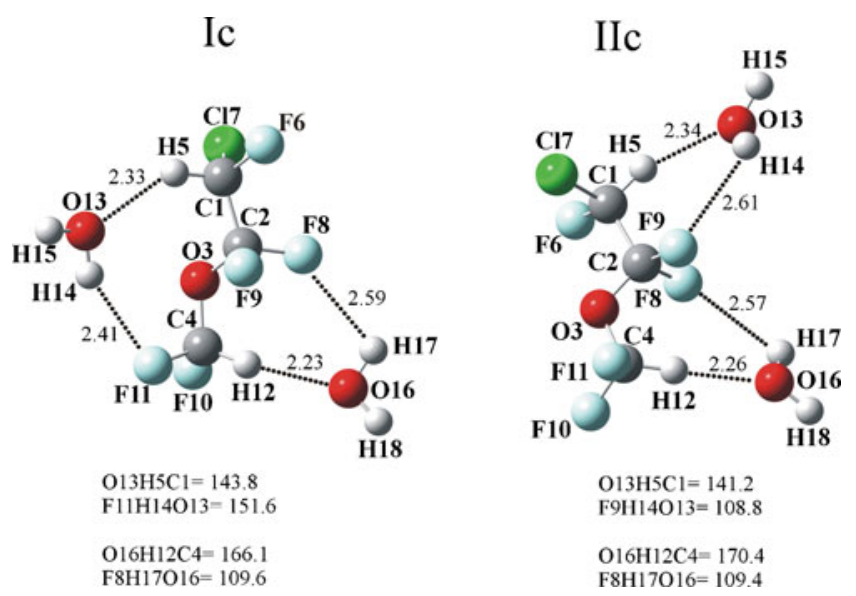

Fig. 3 Structures of enflurane complexes with two water molecules optimized at the MP2/6-311++G(d,p) level. The dot lines indicate selected intermolecular distances (in angstroms), angles are in degrees

the trans conformation are held together by $\mathrm{CH} \ldots \mathrm{F}$ hydrogen bonds [9].

The enthalpy of deprotonation and protonation of the two conformers are presented in Table 1.

In the present systems, the $\mathrm{CH} \ldots \mathrm{O}_{\mathrm{w}}$ hydrogen bond is preferred over the $\mathrm{O}_{\mathrm{w}} \mathrm{H}_{\mathrm{w}} \ldots \mathrm{O}_{3}$. This can be related to a larger basicity $\left(\mathrm{PA}=165 \mathrm{kcalmol}^{-1}\right)$ and a lower acidity (DPE= $390 \mathrm{kcalmol}^{-1}$ ) of water molecule, in comparison to the
Fig. 2 Structures of enflurane complexes with one water molecule optimized at the MP2/ 6-311++G(d,p) level. The dot lines indicate selected intermolecular distances (in angstroms), angles are in degrees

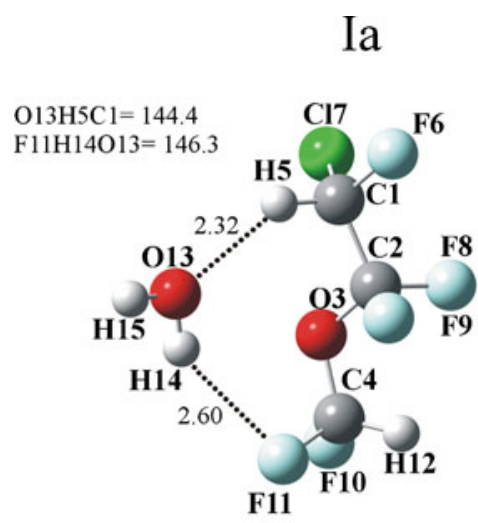

IIa

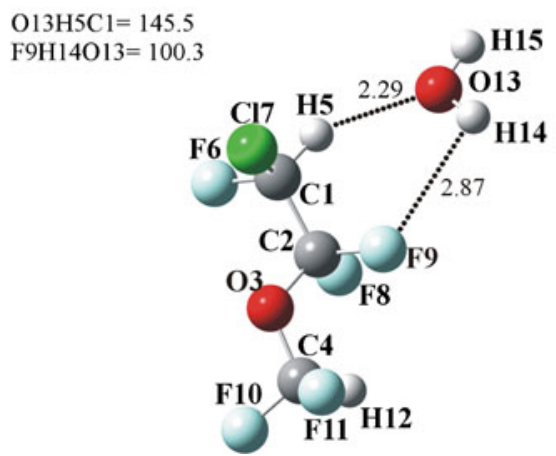

$\mathrm{Ib}$

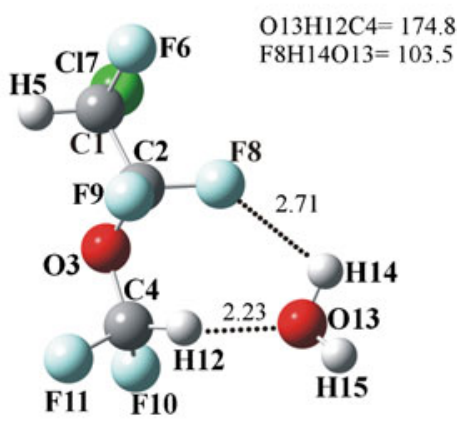

IIb

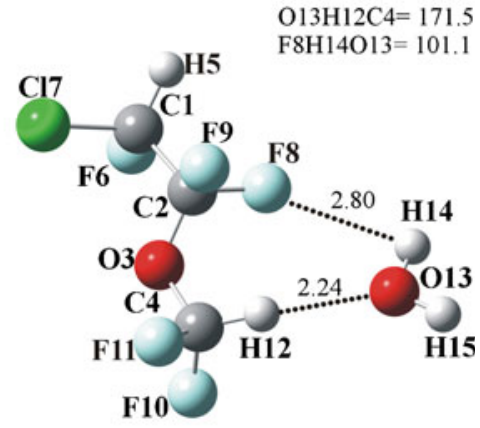


Table 1 Enthalpies of deprotonation of $\mathrm{H}_{5}$ or $\mathrm{H}_{12}$ atoms and proton affinities (PA) of $\mathrm{O}_{3}$ for the two most stable conformers of enflurane (under standard conditions), calculated at the MP2/6-311++G(d,p) and CCSD(T)/CBS levels [all values in $\mathrm{kcalmol}^{-1}$ ]

\begin{tabular}{llll}
\hline Conformer $^{\mathrm{a}}$ & & $\Delta \mathrm{H}^{\mathrm{MP2}}$ & $\Delta \mathrm{H}^{\mathrm{CCSD}(\mathrm{T}) \mathrm{b}}$ \\
\hline $\mathrm{I}$ & $\mathrm{DPE}\left(\mathrm{C}_{1} \mathrm{H}_{5}\right)$ & 365.6 & 363.1 \\
& $\mathrm{DPE}\left(\mathrm{C}_{4} \mathrm{H}_{12}\right)$ & 367.5 & 367.3 \\
& $\mathrm{PA}^{\mathrm{c}}$ & 150.3 & 151.8 \\
II & $\mathrm{DPE}\left(\mathrm{C}_{1} \mathrm{H}_{5}\right)$ & 365.2 & 362.8 \\
& $\mathrm{DPE}\left(\mathrm{C}_{4} \mathrm{H}_{12}\right)$ & 368.6 & 368.1 \\
& PA & 154.5 & 156.4 \\
\hline
\end{tabular}

${ }^{\mathrm{a}}$ The numbering of atoms is shown in Fig. 1

${ }^{\mathrm{b}}$ Calculated as sum of $\Delta \mathrm{E}^{\mathrm{CCSD}(\mathrm{T})}$ and zero-point vibrational energy and thermal correction to enthalpy obtained at the MP2 level

${ }^{\mathrm{c}} \mathrm{PA}=-\Delta \mathrm{H}^{298}$

corresponding values calculated for the two conformers of enflurane. Let us also mention that the complex between $\mathrm{CH}_{3} \mathrm{OCHCl}_{2} \ldots \mathrm{H}_{2} \mathrm{O}\left(\mathrm{PA}(\mathrm{O})=174 \mathrm{kcalmol}^{-1}\right)$ is stabilized by an $\mathrm{O}_{\mathrm{w}} \mathrm{H}_{\mathrm{w}} \ldots \mathrm{O}$ interaction, while in the $\mathrm{CHFClOCHF}_{2} \ldots \mathrm{H}_{2} \mathrm{O}$ complex $\left(\mathrm{PA}(\mathrm{O})=155 \mathrm{kcalmol}^{-1}\right)$, the $\mathrm{CH} \ldots \mathrm{O}_{\mathrm{w}}$ distance is shorter than the $\mathrm{O}_{\mathrm{w}} \mathrm{H}_{\mathrm{w}} \ldots \mathrm{O}$, showing the predominance of the $\mathrm{CH} \ldots \mathrm{O}_{\mathrm{w}}$ hydrogen bond over the $\mathrm{O}_{\mathrm{w}} \mathrm{H}_{\mathrm{w}} \ldots \mathrm{O}$ interaction [27]. In contrast, the complex between $\mathrm{CH}_{2} \mathrm{FCHO}(\mathrm{PA}(\mathrm{O})=161 \mathrm{kcal}$ $\mathrm{mol}^{-1}, \operatorname{DPE}(\mathrm{CH})=352.3 \mathrm{kcalmol}^{-1}$ ) and water shows a preference for a cyclic structure, the $\mathrm{O}_{\mathrm{w}} \mathrm{H}_{\mathrm{w}} \ldots \mathrm{O}$ hydrogen bond being shorter than the $\mathrm{CH} \ldots \mathrm{O}_{\mathrm{w}}$ one [28].

Table 2 lists the binding energies for the interaction of the I and II conformers of enflurane with one water molecule calculated at the MP2/6-311++G(d,p) and $\operatorname{CCSD}(\mathrm{T}) / \mathrm{CBS}$ levels of theory. The CCSD(T)/CBS stabilization energies for the Ia, Ib, IIa and IIb complexes are $-5.89,-5.04,-4.67$ and $-4.66 \mathrm{kcalmol}^{-1}$, respectively. These results indicate that $\mathrm{Ia}$ and $\mathrm{Ib}$ are more stable than the IIa and IIb complexes.

Table 2 Binding energies $\left(\Delta \mathrm{E}^{\mathrm{MP} 2}\right.$ and $\left.\Delta \mathrm{E}^{\mathrm{CCSD}(\mathrm{T})}\right)$ and enthalpies of formation $\left(\Delta \mathrm{H}_{\mathrm{f}}^{\mathrm{MP} 2}\right.$ and $\left.\Delta \mathrm{H}_{\mathrm{f}}^{\mathrm{CCSD}(\mathrm{T})}\right)$ of the enflurane-water complexes, calculated at the MP2/6-311++G(d,p) and CCSD(T)/CBS levels [all values in $\mathrm{kcalmol}^{-1}$ ]

\begin{tabular}{lllll}
\hline & Ia & Ib & IIa & IIb \\
\hline$\Delta \mathrm{E}^{\mathrm{MP2} \text { a }}$ & -4.59 & -4.16 & -3.83 & -3.85 \\
$\Delta \mathrm{E}^{\mathrm{CCSD}(\mathrm{T})}$ & -5.89 & -5.04 & -4.67 & -4.66 \\
$\Delta \mathrm{H}_{\mathrm{f}}^{\mathrm{MP2} \text { b }}$ & -3.06 & -2.73 & -2.43 & -2.42 \\
$\Delta \mathrm{H}_{\mathrm{f}}^{\mathrm{CCSD}(\mathrm{T}) \text { b, c }}$ & -4.35 & -3.58 & -3.29 & -3.22 \\
\hline
\end{tabular}

${ }^{\mathrm{a}}$ Corrected for BSSE

${ }^{\mathrm{b}}$ Enthalpy of formation under standard conditions

${ }^{\mathrm{c}}$ Zero-point vibrational energy and thermal correction to enthalpy obtained at the MP2 level
Table 2 also shows the values of the enthalpies of formation of the enflurane-water complexes, calculated at both levels of theory (under standard conditions in the gas phase). The CCSD(T)/CBS calculated enthalpies of formation are $-4.35,-3.58,-3.29$ and $-3.22 \mathrm{kcal}$ $\mathrm{mol}^{-1}$ for the Ia, Ib, IIa and IIb complexes, respectively. The negative value of enthalpy implies that the formation of the enflurane-water complexes is the exothermic process.

Binding energies and DPEs vary in a very small range and no correlation could be found between these two parameters as in the case of the halogenated ethers and water complexes [27].

Cooperative and anti-cooperative effects have been the subject of many studies [23, 29-34]. Table 3 collects the total binding energies, sum of the pairwise interaction energies and the three-body contribution $\left(\mathrm{E}_{3 \mathrm{~B}}\right)$ to the interaction energies of the two complexes of enflurane with two water molecules (Ic and IIc, shown in Fig. 3), calculated at the MP2/6-311++G(d,p) and CCSD(T)/CBS levels of theory.

As follows from this table, the $\operatorname{CCSD}(\mathrm{T}) / \mathrm{CBS}$ absolute value of the total interaction energy of Ic amounts to $11.41 \mathrm{kcalmol}^{-1}$, and is larger (by $1.85 \mathrm{kcalmol}^{-1}$ ) than that of the complex IIc.

For the Ic complex, the value of $\mathrm{E}_{3 \mathrm{~B}}$ is negative and very small $\left(-0.09 \mathrm{kcalmol}^{-1}\right)$, which indicates that the cooperativity is negligible. In the case of the IIc complex, the value of $E_{3 \mathrm{~B}}$ is positive and small $\left(0.12 \mathrm{kcalmol}^{-1}\right.$, about $1 \%$ of $\left.\Delta \mathrm{E}_{\text {int }}\right)$ which implies the presence of a very weak anticooperative effect.

Examples of the cooperativity effects have been recently illustrated in the cyclic complexes between cycloethers and $\mathrm{H}_{2} \mathrm{O}$ where both $\mathrm{CH} \ldots \mathrm{O}_{\mathrm{w}}$ and $\mathrm{O}_{\mathrm{w}} \mathrm{H}_{\mathrm{w}} \ldots \mathrm{O}$ are strengthened [29]. As expected, with regard to the Ic complex (negligible cooperativity) there is no change in the intermolecular $\mathrm{CH} \ldots \mathrm{O}_{\mathrm{w}}$ distances, in comparison to Ia and $\mathrm{Ib}$, while in the IIc complex (a small anticooperativity) the $\mathrm{C}_{1} \mathrm{H}_{5} \ldots \mathrm{O}_{13}$ and $\mathrm{C}_{4} \mathrm{H}_{12} \ldots \mathrm{O}_{16}$ distances are longer, by 0.05 and $0.02 \AA$, than the corresponding distances in the IIa and IIb complexes, respectively.

Table 3 Total binding interaction energy $\left(\Delta \mathrm{E}_{\text {int }}\right)$, sum of pairwise interaction energies $\left(\Sigma \Delta \mathrm{E}_{2 \mathrm{~B}}\right)$, and the three-body contribution $\left(\mathrm{E}_{3 \mathrm{~B}}\right)$ of enflurane (enf) complexes with water (A and B) molecules. Calculations performed at the MP2/6-311++G(d,p) and $\operatorname{CCSD}(\mathrm{T}) / \mathrm{CBS}$ levels [all values in $\mathrm{kcalmol}^{-1}$ ]

\begin{tabular}{lllll}
\hline & MP2 $^{\mathrm{a}}$ & \multicolumn{3}{c}{$\operatorname{CCSD}(\mathrm{T})$} \\
\hline & Ic & IIc & Ic & IIc \\
$\Delta \mathrm{E}_{\text {int }}$ & -9.01 & -7.60 & -11.41 & -9.56 \\
$\Sigma \Delta \mathrm{E}_{2 \mathrm{~B}}$ & -8.94 & -7.75 & -11.32 & -9.68 \\
$\mathrm{E}_{3 \mathrm{~B}}$ & -0.07 & 0.15 & -0.09 & 0.12 \\
\hline
\end{tabular}

${ }^{a}$ Corrected for BSSE 
The $\mathrm{CH}$ distances and $v(\mathrm{CH})$ vibrational frequencies are collected in Table 4. Complex formation with water results in a contraction of the $\mathrm{CH}$ bond involved in the $\mathrm{CH} . . . \mathrm{O}_{\mathrm{w}}$ interaction along with a blue shift (between 18 and $26 \mathrm{~cm}^{-1}$ ) of the corresponding vibration. Blue shifts of the same order of magnitude (between 19 and $25 \mathrm{~cm}^{-1}$ ) were predicted for the complexes between enflurane and acetone (I conformer, bound with water at the $\mathrm{C}_{1} \mathrm{H}_{5}$ and $\mathrm{C}_{4} \mathrm{H}_{12}$ sites) [13]. As seen in Table 4, an IR intensity increase was predicted for the complexes formed at the $\mathrm{C}_{1} \mathrm{H}_{5}$ bond, while an IR intensity decrease was predicted for the complexes formed at the $\mathrm{C}_{4} \mathrm{H}_{12}$ bond. Let us notice that the analogous variations of IR intensity have been observed experimentally [13] in our earlier work on enflurane complexes with acetone.

The selected results from the NBO analysis are collected in Table 5. As seen in this table, the change in electron density in the $\sigma(\mathrm{CH})$ orbital is small. The contraction of the $\mathrm{C}_{1} \mathrm{H}_{5}$ and $\mathrm{C}_{4} \mathrm{H}_{12}$ bonds mainly results from the decrease in occupancy of the corresponding $\sigma^{*}(\mathrm{CH})$ orbital. A small increase of the s-character of the $\mathrm{C}$ atom may also contribute to this contraction, which has been largely discussed in earlier works [35-43]. The interaction with water also leads

Table $4 \mathrm{C}-\mathrm{H}$ distances $\left(\mathrm{r}\right.$ in $\AA$ ), frequencies $\left(\nu\right.$ in $\left.\mathrm{cm}^{-1}\right)$ and corresponding infrared intensities (A in $\mathrm{kmmol}^{-1}$ ) of $\mathrm{C}-\mathrm{H}$ stretching vibration in two conformers of enflurane and their complexes with water molecules. Calculations performed at the MP2/6-311++G(d,p) level

\begin{tabular}{|c|c|c|c|c|c|c|}
\hline $\mathrm{C}_{1}-\mathrm{H}_{5}{ }^{\mathrm{a}}$ & $\mathrm{R}$ & $\Delta \mathrm{r}^{\mathrm{b}}$ & $v$ & $\Delta v^{\mathrm{c}}$ & A & $\Delta \mathrm{A}^{\mathrm{d}}$ \\
\hline I & 1.090 & & 3185 & & 5 & \\
\hline Ia & 1.089 & -0.001 & 3204 & +19 & 11 & +6 \\
\hline $\mathrm{Ib}$ & 1.090 & 0.000 & 3186 & +1 & 5 & 0 \\
\hline Ic & 1.089 & -0.001 & 3203 & +18 & 11 & +6 \\
\hline II & 1.090 & & 3176 & & 5 & \\
\hline IIa & 1.089 & -0.001 & 3202 & +26 & 12 & +7 \\
\hline $\mathrm{IIb}$ & 1.090 & 0.000 & 3175 & -1 & 6 & +1 \\
\hline IIc & 1.089 & -0.001 & 3199 & +23 & 7 & +2 \\
\hline \multicolumn{7}{|l|}{$\mathrm{C}_{4}-\mathrm{H}_{12}$} \\
\hline I & 1.089 & & 3210 & & 12 & \\
\hline Ia & 1.088 & 0.000 & 3215 & +5 & 11 & -1 \\
\hline $\mathrm{Ib}$ & 1.088 & -0.001 & 3229 & +19 & 7 & -5 \\
\hline Ic & 1.088 & -0.001 & 3233 & +23 & 7 & -5 \\
\hline II & 1.089 & & 3205 & & 14 & \\
\hline IIa & 1.089 & 0.000 & 3205 & 0 & 15 & +1 \\
\hline $\mathrm{IIb}$ & 1.088 & -0.001 & 3229 & +24 & 6 & -8 \\
\hline IIc & 1.088 & -0.001 & 3226 & +21 & 4 & -10 \\
\hline
\end{tabular}

${ }^{\mathrm{a}}$ The corresponding structures are shown in Figs. 1 and 2,

${ }^{\mathrm{b}}$ Changes in the bond length in comparison to the isolated conformer,

${ }^{\mathrm{c}}$ Changes in the $v(\mathrm{C}-\mathrm{H})$ frequency in comparison to the isolated conformer,

${ }^{\mathrm{d}}$ Changes in the IR intensity (A)
Table 5 Electron density in the $\sigma(\mathrm{CH})$ and $\sigma^{*}(\mathrm{CH})$ orbitals and the scharacter of the valence orbital on the $\mathrm{C}$ atom (in \%) in isolated I and II conformers and their complexes with $\mathrm{H}_{2} \mathrm{O}$

\begin{tabular}{|c|c|c|c|c|c|c|}
\hline $\mathrm{C}_{1}-\mathrm{H}_{5}$ & $\sigma$ & $\Delta \sigma^{\mathrm{a}}$ & $\sigma^{*}$ & $\Delta \sigma^{* \mathrm{~b}}$ & $\begin{array}{l}\% \text { s- } \\
\text { char }\end{array}$ & $\begin{array}{l}\Delta \% \mathrm{~s}^{-} \\
\text {char }^{\mathrm{c}}\end{array}$ \\
\hline I & 1.9860 & & 0.0297 & & 27.2 & \\
\hline Ia & 1.9855 & -0.0005 & 0.0279 & -0.0018 & 28.3 & 1.1 \\
\hline $\mathrm{Ib}$ & 1.9860 & 0.0000 & 0.0296 & -0.0001 & 27.2 & 0 \\
\hline Ic & 1.9854 & -0.0006 & 0.0278 & -0.0019 & 28.2 & 1 \\
\hline II & 1.9871 & & 0.0294 & & 26.8 & \\
\hline IIa & 1.9868 & -0.0003 & 0.0276 & -0.0018 & 28 & 1.2 \\
\hline $\mathrm{IIb}$ & 1.9873 & 0.0002 & 0.0294 & 0.0000 & 26.8 & 0 \\
\hline IIc & 1.9869 & -0.0002 & 0.0276 & -0.0018 & 27.9 & 1.1 \\
\hline \multicolumn{7}{|l|}{$\mathrm{C}_{4}-\mathrm{H}_{12}$} \\
\hline I & 1.9942 & & 0.0347 & & 30.2 & \\
\hline Ia & 1.9943 & 0.0001 & 0.0340 & -0.0007 & 30.3 & 0.1 \\
\hline $\mathrm{Ib}$ & 1.9944 & 0.0002 & 0.0331 & -0.0016 & 31.4 & 1.2 \\
\hline Ic & 1.9943 & 0.0001 & 0.0326 & -0.0021 & 31.6 & 1.4 \\
\hline II & 1.9942 & & 0.0352 & & 30.1 & \\
\hline IIa & 1.9942 & 0.0000 & 0.0354 & +0.0002 & 30 & -0.1 \\
\hline $\mathrm{IIb}$ & 1.9943 & 0.0001 & 0.0334 & -0.0018 & 31.4 & 1.3 \\
\hline IIc & 1.9943 & 0.0001 & 0.0334 & -0.0018 & 31.3 & 1.2 \\
\hline
\end{tabular}

a, b, c Changes of $\sigma, \sigma^{*}$ and s-char, respectively, caused by interaction with water molecules

to a decrease of the positive charge on $\mathrm{C}$ and an increase of this charge on the $\mathrm{H}$ atom.

The values of the hyperconjugation energies $\left(E^{2}\right)$ in the isolated conformers and their $\mathrm{H}_{2} \mathrm{O}$ complexes are collected in Table 6. In all the systems, there is an intermolecular charge transfer from the lone pair orbital (LP) of the $\mathrm{O}$ atom of water $\left(\mathrm{O}_{\mathrm{w}}\right)$ to the $\sigma^{*}\left(\mathrm{C}_{1} \mathrm{H}_{5}\right)$ or $\sigma^{*}\left(\mathrm{C}_{4} \mathrm{H}_{12}\right)$ orbitals, as indicated by the corresponding second-order interaction energies $\left(E^{2}\right.$ inter $)$ in Table 6. These energies are moderate, ranging from 1.8 to $3.6 \mathrm{kcalmol}^{-1}$, and are somewhat larger for the complexes formed at the $\mathrm{C}_{4} \mathrm{H}_{12}$ bond.

Finally, it should be noted that the interaction between enflurane and water results in a small perturbation of the normal vibrational modes of water. For the Ic(1) complex as for example, the $v^{\text {as }}$ and $v^{\mathrm{s}}(\mathrm{OH})$ stretching frequencies are red-shifted, by 13 and $12 \mathrm{~cm}^{-1}$, respectively, while the

Table 6 Intermolecular second-order interaction energies $\left(E^{2}\right.$, kcal $\mathrm{mol}^{-1}$ ) in the I and II complexes of enflurane with $\mathrm{H}_{2} \mathrm{O}$

\begin{tabular}{lllll}
\hline & $\mathrm{I}$ & $\mathrm{Ia}$ & $\mathrm{Ib}$ & $\mathrm{Ic}$ \\
$\mathrm{LPO}_{\mathrm{w}} \rightarrow \sigma^{*}\left(\mathrm{C}_{1} \mathrm{H}_{5}\right)$ & - & 1.94 & - & 1.84 \\
$\mathrm{LPO}_{\mathrm{w}} \rightarrow \sigma^{*}\left(\mathrm{C}_{4} \mathrm{H}_{12}\right)$ & - & - & 3.61 & 3.54 \\
& $\mathrm{II}$ & $\mathrm{IIa}$ & $\mathrm{IIb}$ & $\mathrm{IIc}$ \\
$\mathrm{LPO}_{\mathrm{w}} \rightarrow \sigma^{*}\left(\mathrm{C}_{1} \mathrm{H}_{5}\right)$ & - & 2.12 & - & 1.76 \\
$\mathrm{LPO}_{\mathrm{w}} \rightarrow \sigma^{*}\left(\mathrm{C}_{4} \mathrm{H}_{12}\right)$ & - & - & 3.50 & 3.19 \\
\hline
\end{tabular}


$\delta(\mathrm{OH})$ bond frequency is blue-shifted by $12 \mathrm{~cm}^{-1}$. It is also worth stressing that in contrast to most of the $\mathrm{OH}$... hydrogen bonds, the intensity ratio $\mathrm{v}^{\text {as }}(\mathrm{OH}) / v^{\mathrm{s}}(\mathrm{OH})$ is larger than 1 . The same trend was also predicted for complexes between fluorinated ethers and water [28].

Halogen bonded enflurane complexes with water

Studies of the electrostatic potentials of the halogen bonded systems show that the lone electron pairs of the halogen atom bonded to the carbon atom form a belt of negative electrostatic potential around its central part leaving the outermost region positive, the so called $\sigma$-hole $[44,45]$. The halogen bonding was explained as a noncovalent interaction between a covalently bound halogen on one molecule and a negative site of another [44-49].

The structures of the halogen bonded enflurane $\cdots \mathrm{OH}_{2}$ complexes optimized at the MP2/6-311++G(d,p) level are illustrated in Fig.4.

The $\mathrm{C}_{1}-\mathrm{Cl}_{7}$ bond distance is equal to $1.748 \AA$ in two complexes, thus, it is shorter by $-0.004 \AA$ relative to that in the enflurane monomers $(1.752 \AA)$. The contraction of this bond is concomitant with an increase of the $v\left(\mathrm{C}_{1}-\mathrm{Cl}_{7}\right)$ stretching frequency (blue-shift) by +2 and $+4 \mathrm{~cm}^{-1}$, in the Id and IId complexes, respectively. The infrared intensities of the corresponding stretching mode decrease by 6 and $12 \mathrm{kmmol}^{-1}$, respectively.

As depicted in Fig.4, the intermolecular $\mathrm{Cl}_{7} \cdots \mathrm{O}_{13}$ distances in the Id and IId complexes are equal to 3.17 and $3.18 \AA$, respectively. These values are smaller than the sum of the van der Waals radii of the chlorine and oxygen atoms, $3.27 \AA[50]$. The analogous ( $\mathrm{Cl} \cdots \mathrm{O})$ distance, in the halogen bonded enflurane $\cdots$ formaldehyde complex was found to be $3.30 \AA[12]$.

In biological molecules with the halogen bond, the average $\mathrm{C}-\mathrm{Cl} \cdots \mathrm{O}$ angle is between $160^{\circ}$ and $180^{\circ}$ [51]. In the Id and IId complexes, the $\mathrm{C}_{1}-\mathrm{Cl}_{7} \cdots \mathrm{O}_{13}$ angles are 176.8 and $166.3^{\circ}$, respectively.

Id

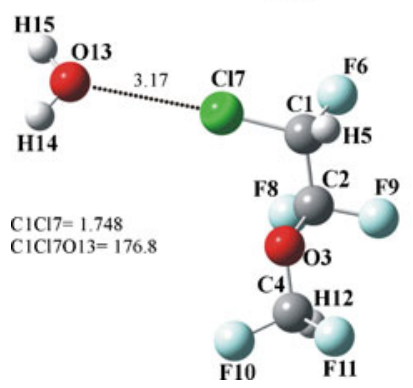

Fig. 4 Structures of halogen bonded complexes of enflurane with water molecule optimized at the MP2/6-311++G(d,p) level. The dot lines indicate selected intermolecular distances (in angstroms), angles are in degrees
NBO analysis has revealed that in the halogen bonded enflurane $\cdots$ water complexes, the $\mathrm{Cl}$ atom shows the largest change of the atomic charge, in comparison to isolated molecules. In Id and IId, the charge on $\mathrm{Cl}$ increases by 0.026 and $0.023 \mathrm{e}$, respectively.

As was mentioned earlier, the chlorine atom has three lone electron pairs which form a belt of negative electrostatic potential around the central part of this atom, leaving the outermost region positive ( $\sigma$-hole). The oxygen atom of water has two lone pair orbitals. One of them $\left(\mathrm{LP}(2) \mathrm{O}_{13}\right)$ is involved in the formation of the halogen bond, and it overlaps with the $\sigma^{*}\left(\mathrm{C}_{1} \mathrm{Cl}_{7}\right)$ orbital of enflurane. In both the complexes considered, the second-order interaction energies $\left(\mathrm{E}^{2}\right)$ between the donor $\left(\mathrm{LP}(2) \mathrm{O}_{13}\right)$ and acceptor $\left(\sigma^{*}\right.$ $\left(\mathrm{C}_{1} \mathrm{Cl}_{7}\right)$ ) orbitals are smaller than $0.5 \mathrm{kcalmol}^{-1}$.

The CCSD(T)/CBS stabilization energies for the Id and IId complexes are -1.81 and $-1.89 \mathrm{kcalmol}^{-1}$, respectively. Thus, the halogen bonded enflurane $\cdots \mathrm{OH}_{2}$ complexes are weaker than the hydrogen bonded enflurane $\cdots \mathrm{OH}_{2}$ complexes, by more than $3 \mathrm{kcalmol}^{-1}$.

\section{Conclusions}

1) In the enflurane complexes with one and two water molecules, the $\mathrm{CH} \ldots \mathrm{O}_{\mathrm{w}}$ hydrogen bonds are formed, with the $\mathrm{CH} \ldots \mathrm{O}_{\mathrm{w}}$ distances varying between 2.23 and $2.32 \AA$. A weak interaction between one of the $\mathrm{F}$ atoms and the $\mathrm{H}$ atom of water is also possible, the $\mathrm{H}_{\mathrm{w}} \ldots \mathrm{F}$ distances being longer (between 2.41 and $2.87 \AA$ ). No stable $\mathrm{O}_{\mathrm{w}} \mathrm{H}_{\mathrm{w}} \ldots \mathrm{O}_{\text {enf }}$ complex has been found on the potential energy surface. This is line with our earlier results on enflurane dimer [9], where we have shown that the $\mathrm{O}$ atoms of enflurane $\left(\mathrm{O}_{\mathrm{enf}}\right)$ do not participate in hydrogen bonding.

2) The $\mathrm{CH}$ bonds involved in the $\mathrm{CH} . . \mathrm{O}_{w}$ interaction are contracted with respect to those in isolated enflurane. This is accompanied by a blue shift (between 18 and $26 \mathrm{~cm}^{-1}$ ) of the corresponding $v(\mathrm{C}-\mathrm{H})$ stretching frequencies. For $v(\mathrm{C}$ $-\mathrm{H})$ vibrations an increase of the IR intensity was predicted for the complexes formed at the $\mathrm{C}_{1} \mathrm{H}_{5}$ bond, while a decrease of the IR intensity was calculated for the complexes formed at the $\mathrm{C}_{4} \mathrm{H}_{12}$ bond. Similar effects have been found in our earlier experimental and theoretical studies of the enflurane complexes with acetone [13].

3) The CCSD(T)/CBS stabilization energies of the hydrogen bonded enflurane-water complexes vary between -5.89 and $-4.66 \mathrm{kcalmol}^{-1}$. The values of the enthalpies of formation of these complexes, calculated at the same level of theory, range between -4.35 and $-3.22 \mathrm{kcalmol}^{-1}$.

4) The CCSD(T)/CBS calculated three-body contribution to the total binding energy of the hydrogen bonded enflurane complex with two water molecules shows that the cooperativity effects are very weak. 
5) The $\mathrm{Cl}$ halogen bonding has been found in two enflurane complexes with water. The intermolecular $(\mathrm{Cl} \cdots \mathrm{O})$ distances ( 3.17 and $3.18 \AA$ ) are smaller than the sum of the corresponding van der Waals radii. The CCSD(T)/CBS stabilization energies for these complexes are -1.81 and $-1.89 \mathrm{kcalmol}^{-1}$. This indicates that the halogen bonded enflurane $\cdots \mathrm{OH}_{2}$ complexes are weaker than the hydrogen bonded enflurane-water complexes.

Acknowledgments The work was financed by a statutory activity subsidy from the Polish Ministry of Science and Higher Education for the Faculty of Chemistry of Wrocław University of Technology. Generous computer time from the Wroclaw Supercomputer and Networking Center as well as Poznan Supercomputer and Networking Center is acknowledged.

Open Access This article is distributed under the terms of the Creative Commons Attribution License which permits any use, distribution, and reproduction in any medium, provided the original author(s) and the source are credited.

\section{References}

1. Franks NP, Lieb WR (1994) Nature 367:607-614

2. Sandorfy C (2004) Anesthesiology 101:1225-1227

3. Sandorfy C (2004) J Mol Struct 708:3-5

4. Liu R, Loll PJ, Eckenhoff RG (2005) FASEB J 19:567-576

5. Campagna-Slater V, Weaver DF (2007) Neurosci Lett 418:28-33

6. Cui T, Bondarenko V, Ma D, Canlas C, Brandon N, Johansson J, Xu Y, Tang P (2008) Biophys J 94:4464-4472

7. Balonga PE, Kowalewski VJ, Contraras RH (1988) Spectrochim Acta 44A:819-822

8. Pfeiffer A, Mack H-G, Oberhammer H (1998) J Am Chem Soc 120:6384-6388

9. Michalska D, Bieńko D, Czarnik-Matusewicz B, Wierzejewska M, Sandorfy C, Zeegers-Huyskens T (2007) J Phys Chem A 111:12228-12238

10. Zierkiewicz W, Michalska D, Zeegers-Huyskens T (2009) J Mol Struct (Theochem) 911:58-64

11. Zierkiewicz W (2010) Chem Phys 373:243-250

12. Zierkiewicz W, Wieczorek R, Hobza P, Michalska D (2011) Phys Chem Chem Phys 113:5105-5113

13. Zierkiewicz W, Czarnik-Matusewicz B, Michalska D (2011) J Phys ChemA 115:11362-11368

14. Andersen MPS, Nielsen OJ, Karpichev B, Wallington TJ, Sander SPJ (2012) J Phys Chem A 116:5806-5820

15. Dalmasso PR, Taccone RA, Nieto JD, Teruel MA, Lane SI (2006) Atm Envirom 40:7298-7307

16. Krishnan R, Binkley JS, Seeger R, Pople JA (1980) J Chem Phys $72: 650-654$

17. Frisch MJ, Pople AJ, Binkley JS (1984) J Chem Phys 80:3265-3269

18. Boys SF, Bernardi F (1970) Mol Phys 19:553-566

19. Pople JA, Seeger R, Krishnan R (1977) Int J Quantum Chem Symp 11:149-163

20. Halkier A, Helgaker T, Jorgensen P, Klopper W, Koch H, Olsen J, Wilson AK (1998) Chem Phys Lett 286:243-252

21. Kendall RA, Dunning TH Jr, Harrison RJ (1992) J Chem Phys 96:6796-6806

22. Dunning TH Jr (1989) J Chem Phys 90:1007-1023
23. Antony J, Brüske B, Grimme S (2009) Phys Chem Chem Phys 11:84408447

24. Glendening ED, Reed AE, Carpenter JE, Weinhold F (1996) NBO 3.1 Theoretical Chemistry Institute. University of Wisconsin, Madison, WI

25. http://www.chem.wisc.edu/ nbo5 Homepage of NBO

26. Frisch MJ, Trucks GW, Schlegel HB, Scuseria GE, Robb MA, Cheeseman JR, Scalmani G, Barone V, Mennucci B, Petersson GA, Nakatsuji H, Caricato M, Li X, Hratchian HP, Izmaylov AF, Bloino J, Zheng G, Sonnenberg JL, Hada M, Ehara M, Toyota K, Fukuda R, Hasegawa J, Ishida M, Nakajima T, Honda Y, Kitao O, Nakai H, Vreven T, Montgomery Jr JA, Peralta JE, Ogliaro F, Bearpark M, Heyd JJ, Brothers E, Kudin KN, Staroverov VN, Kobayashi R, Normand J, Raghavachari K, Rendell A, Burant JC, Iyengar SS, Tomasi J, Cossi M, Rega N, Millam JM, Klene M, Knox JE, Cross JB, Bakken V, Adamo C, Jaramillo J, Gomperts R, Stratmann RE, Yazyev O, Austin AJ, Cammi R, Pomelli C, Ochterski JW, Martin RL, Morokuma K, Zakrzewski VG, Voth GA, Salvador P, Dannenberg JJ, Dapprich S, Daniels AD, Farkas O, Foresman JB, Ortiz JV, Cioslowski J, Fox DJ (2009) Gaussian 09 Rev B.01 Gaussian Inc, Wallingford

27. Zierkiewicz W, Michalska D, Zeegers-Huyskens T (2010) Phys Chem Chem Phys 12:13681-13691

28. Parveen S, Chandra AK, Zeegers-Huyskens T (2009) J Phys Chem A 113:6182-6191

29. Vallejos MM, Angelina E, Peruchena NM (2010) J Phys Chem A 114:2855-2863

30. Huyskens PL (1977) J Am Chem Soc 99:2578-2582

31. Kar T, Scheiner S (2004) J Phys Chem A 108:9161-9168, and references therein

32. Chandra AK, Zeegers-Huyskens T (2012) J Comput Chem 33:1131-1141

33. Dannenberg JJ (2002) J Mol Struct 615:219-226

34. Zierkiewicz W, Michalska D, Hobza P (2010) Phys Chem Chem Phys 12:2888-2894

35. Gu Y, Kar T, Scheiner S (1999) J Am Chem Soc 121:9411-9422

36. Hobza P, Havlas Z (2000) Chem Rev 100:4253-4264

37. Van der Veken BJ, Herrebout WA, Szostak R, Shcherpkin DN, Havlas Z, Hobza P (2001) J Am Chem Soc 123:12290-12293

38. Kryachko ES, Zeegers-Huyskens T (2001) J Phys Chem A 105:7118-7125

39. Zierkiewicz W, Michalska D, Havlas Z, Hobza P (2002) ChemPhysChem 3:511-518

40. Hermansson K (2002) J Phys Chem A 106:4695-4702

41. Alabugin IV, Manoharan M, Peabody S, Weinhold F (2003) J Am Chem Soc 125:5973-5987

42. Karpfen A, Kryachko ES (2006) Chem Phys Lett 431:428-433

43. Joseph J, Jemmis ED (2007) J Am Chem Soc 129:4620-4632

44. Clark T, Hennemann M, Murray JS, Politzer P (2007) J Mol Model 13:291-296

45. Politzer P, Lane P (2007) Concha MC, Ma Y, Murray JS. J Mol Model 13:305-311

46. Alkorta I, Blanco F, Solimannejad M, Elguero J (2008) J Phys Chem A 112:10856-10863

47. Politzer P, Murray JS, Concha MC (2008) J Mol Model 14:659665

48. Lommerse JPM, Stone AJ, Taylor R, Allen FH (1996) J Am Chem Soc 118:3108-3116

49. Metrangolo P, Neukirch H, Pilati T, Resnati G (2005) Acc Chem Res 38:386-395

50. Bondi A (1964) J Phys Chem 68:441-452

51. Auffinger P, Hays FA, Westhof E, Ho PS (2004) Proc Natl Acad Sci USA 101:16789-16794 